\title{
Eco friendly printing of cotton with Kachnar bark dye
}

\author{
SAROJ YADAV, GEETA GABA AND SAROJ S. JEET SINGH
}

Received: 27.02.2016; Revised: 21.04.2016; Accepted: 03.05.2016

See end of the paper for authors' affiliations

\section{SAROJ YADAV}

Department of Textile and Apparel Designing, I.C. College of Home

Science, C.C.S. Haryana

Agricultural University, HISAR (HARAYANA) INDIA

\begin{abstract}
Textile printing involves the production of a predetermined coloured pattern on a fabric, usually with a definite repeat. In India dyeing and printing with natural dyes is an age old practice. Today's scene of natural dye promotion is very optimistic and promising. The scientists and textile technologists of various institutions have started working on natural dyes as a possible means of producing ecologically sound products which would appeal to green minded consumers. Keeping in view the importance of natural dyes in textile world a study was conducted to print cotton fabric with kachnar bark dye using Cassia tora gum. Cotton fabric was scoured to remove impurities. Dried kachnar bark was grounded to make powder, 8 per cent dye was extracted by boiling in water, strained to get dye extract. Extracted dye was evaporated to make $10 \mathrm{ml}$. dye concentrate. Two concentrations i.e. 2.5 and 5 per cent of Cassia tora gum powder was used as natural thickner. Paste of thickener was prepared by adding lukewarm water and added to dye concentrate for making printing paste. Copper sulphate and ferrous sulphate were used as mordants. Printing was done by block and screen printing techniques. Printed samples were dried in sun, cured for three days and steamed in laboratory steamer. The printed samples were evaluated visually for depth of colour, evenness of print, sharpness of print and overall appearance. Fastness of printed samples was studied against, sunlight, washing, rubbing and perspiration using standard test methods. Results of the study revealed that for visual evaluation screen printed samples scored higher as compared to block printed samples. The fastness ratings against different agencies ranged from good (3) to excellent (5). The fastnesses as well as visual evaluation grades of Cassia tora gum were comparable with guar gum used as controlled thickner, hence Cassia tora gum can be used effectively for printing of cotton.
\end{abstract}

KEY WORDS: Printing, Kachnar bark, Cassia tora, Mordant, Thickener, Visual evaluation, Fastness

- HOW TO CITE THIS PAPER : Yadav, Saroj, Gaba, Geeta and Singh, Saroj S. Jeet (2016). Eco friendly printing of cotton with Kachnar bark dye. Asian J. Home Sci., 11 (1) : 106-110, DOI: 10.15740/ HAS/AJHS/11.1/106-110. 